\title{
HOW MUCH IS A PUMA WORTH? ECONOMIC COMPENSATION AS AN ALTERNATIVE FOR THE CONFLICT BETWEEN WILDLIFE CONSER- VATION AND LIVESTOCK PRODUCTION IN BRAZIL
}

\author{
Luciano M. Verdade \& Cláudia B. Campos
}

Biota Neotropica v4 (n2)-http://www.biotaneotropica.org.br/v4n2/pt/abstract?short-communication+BN02204022004

\author{
Date received: 01/28/2004 \\ Revised: 06/24/2004 \\ Accepted: 07/01/2004
}

\author{
Laboratório de Ecologia Animal / LZT / ESALQ / USP \\ Caixa Postal 09 \\ Piracicaba, SP 13418-900 BRASIL \\ Fone: 55-19-34294223 \\ Fax: 55-19-34294055 \\ Email:1mv@esalq.usp.br
}

\begin{abstract}
In this article a case of sheep predation by pumas is presented and used as an example for evaluating the damage and the cost of economic compensation mitigating action for the conflicts between wildlife conservation and livestock production in Brazil. The relative advantages of this kind of action are discussed, considering the Brazilian scenario.
\end{abstract}

Key words: conservation, wildlife management, damage control, puma, carnivore, extension

\section{Resumo}

No presente artigo, um caso de predação de ovelhas por pumas é apresentado e usado como exemplo para o cálculo de danos e do custo da compensação econômica como medida mitigadora dos conflitos entre a conservação da fauna e a produção animal no Brasil. As vantagens deste tipo de medida em relação a outras são discutidas no contexto brasileiro.

Palavras-chave:conservação, manejo de fauna, controle de danos, pumas, carnívoros, extensão 
Hunting is forbidden in Brazil since 1967 (Federal Law No. 5.197 from January 1967). According to Brazilian legislation, wildlife belongs to the state, not to landowners. However, in recent years, there has been an increasing number of wildlife-livestock conflicts with losses to both sides. This is especially true for regions such as the State of São Paulo, which is one of the most developed areas of Brazil and, at the same time, harbors one of the largest portions of remaining Atlantic Forest. Human-wildlife conflicts are becoming one of the major concerns for conservation biologists in the world for three basic reasons: humans are increasingly entering remote carnivore habitats, many largecarnivore populations are recovering due to conservation efforts, and affected communities demand urgent responses (Treves \& Karanth 2003). Because Brazil does not have a Wildlife Service as in other countries, wildlife damage is usually not officially evaluated and wildlife conservation efforts are ineffective.

Here, we describe a case of conflict between wildlife conservation and livestock production in the State of São Paulo, Brazil, involving pumas. In 1997, a paper industry cut a few thousand hectares of Eucalyptus plantation in southern São Paulo State. Approximately 20 days latter a 2,300 ha neighbor sheep ranch began to suffer puma damage. During the next 12 months, pumas preyed 60 sheep and local hunters killed seven pumas including a nursing female. $\mathrm{Pu}-$ mas were identified as the predators by the ranch manager in all cases and by one of us (LMV) in the last three cases. Pumas kill with bites inflicted from above, often hurting the vertebral column and breaking the neck of the prey (Hawthorne 1980, Cavalcanti 2003). They also may kill by biting through the skull of small preys (Bowns 1976). The sheep rancher estimated total damage as US\$3,600 based on local market prices of sheep meat.

Some months latter, the same sheep rancher had a dog attack on his sheep herd resulting in 21 sheep killed on a single night. However, no dog was hunted afterwards because they belonged to the rancher's neighbor. In this case, the dog was identified by some of the ranch's employees during the attack. Dogs normally wound the prey in the neck, front shoulders and ears (Bowns 1976, Cavalcanti 2003). However, contrary to pumas, dogs often attack the hindquarters of the sheep, but little flesh is consumed (Hawthorne 1980).

Wildlife predation on livestock can be minimized through some preventive actions. Caughley \& Sinclair (1994) suggest that the first step is to identify the real damage. In general, conflicts arise from the encounter between wildlife and livestock and they should be kept apart. On a large scale this can be done by zoning land use, for example forbidding livestock in a buffer zone around National Parks or large natural areas (Campbell \& Hofer 1995). On a smaller scale this can be done by improving livestock management inside the property through fencing (Huygens \& Hayashi 1999, O’Connel-Rodwell et al. 2000), night sheltering (Vieira 1967, Ciucci \& Boitani 1998), dog guarding (Andelt 1992, Andelt \& Hopper 2000), and using frightening devices (Dolbeer et al. 1996). For all these options, the correct identification of the predator is essential to an effective carnivore damage control. Feral dogs and cats are usually underestimated and misidentified as livestock predators (Nesbitt 1983, Churcher \& Lawton 1987). Tracks, marks on trees, historical reports, and of course direct sighting are indicative of the predators presence in the area. However, carcass disposition is possibly the best way to identify the actual predator (Dolbeer et al. 1996).

When preventing the encounter between carnivores and livestock is not feasible, the following control systems have been applied: non-lethal techniques (Shivik et al. 2003), translocation of problem animals (Ruth et al. 1998, Abbott 2000), compensation of economic losses (Wagner et al. 1997, Naughton-Treves et al. 2003), culling or sport hunting of problem animals (Hoogesteijn et al. 1993), population density reduction (Greentree et al. 2000, Landa et al. 1999), and eradication (Harris and Saunders 1993, Conner et al. 1998). Non-lethal techniques usually involve the use of predator repellents (Musiani et al. 2003, Shivik et al. 2003) and/or fencing (Allen \& Sparkes 2001, Ogada et al. 2003). Translocations are usually expensive and ineffective because they require considerable logistics including available sites and trained personnel, and problem individuals usually keep presenting behavioral problems in the new areas where they are released (Hoogesteijn et al. 1993). Economic compensation requires an effective program of damage identification and evaluation to avoid fraud (Hueting 1991, Cozza et al. 1996). Culling problem individuals is possibly the least expensive method of damage control. In general, local people can identify the specific individual causing damage and the problem is solved at the moment the animal is killed. As suggested by Hoogesteijn et al. (1993), sport hunting of problem individuals would also generate economic income for the property where damage occurred. In both systems, however, wildlife populations monitoring and correct and precise identification of problem individuals is required. Moreover, sport hunting is forbidden in Brazil and public opinion may be considerably sensitive about it, especially in urban areas of southern Brazil.

On the other hand, managing wildlife damage at the population level (population density reduction and eradication) may lead local people to identify the species as the problem, not specific individuals. This may result in unnecessary culling, potentially putting conservation of large predators under risk.

The basic difference between the systems above is that one of them (compensation) deals with the subject and the effects of damage and the others with the object and 
cause of damage. In a country without an effective wildlife service, economic compensation at a first glance may seem inappropriate because of a high probability of frauds. However, even considering that some overestimating of economic loss may occur, the overall cost of compensation may not be too high, as exemplified in the case reported above. Seven pumas were killed because of a loss of US\$ 3,600 , leading to a value US\$ 514.29 per year per puma.

Ranchers are not willing to pay for the conservation of animals that cause loss to their main economic activity. However, if compensated for those losses, they would be stimulated to keep big predators on their land and this would be possibly the cheapest way to promote the conservation of these species (Naughton-Treves et al. 2003). As a government strategy, this could be considered a kind of agricultural subsidy like many others. In order to implement such strategy in Brazil, at least three steps would be necessary: change wildlife law (Magnusson, 1993, Mourão 1999), improve formation of wildlife biologists (Verdade 2001), and use the already existing infrastructure of the Agriculture Extension Service (Casas da Agricultura) (Verdade 2001).

Brazilian Federal Law No. 5.197 / 67 should be modified in order to distinguish endangered from abundant species that could or should be managed for their economic importance either as renewable resources or plagues (Magnusson, 1993, Mourão 1999). The management of such species can be normally self-sustained because it can generate or save funds. On the other hand, endangered species require full protection and should be prioritized by the government for funding.

Contrary to other countries, there is no tradition of wildlife management in higher-level education of biologists in Brazil. Although, there is an increasing concern about the possible "social implications" of biological problems (Krasilchik 2003), wildlife management is not yet included on the curricula of Biology undergraduate courses in Brazil (Verdade 2001).

Although Casas da Agricultura have problems like any other Brazilian government institution they are widespread in the country. Local wildlife biologists working for such institution could be easily trained to identify wildlife damage (Verdade 2001). This way an effective compensation program for large carnivore predation on livestock could be implemented at a relatively low cost and pumas could be possibly kept where they live.

\section{Acknowledgements}

Adilson Carmignani provided us access to the sheep ranch and helped in field evaluation of puma's predation. Peter Crawshaw gave us background information and inputs on the problem of large carnivores predation on livestock.

\section{Literature Cited}

Аввотт, I. 2000. Improving the conservation of threatened and rare mammal species through translocation to islands: case study Western Australia. Biological Conservation 93:195-201.

Allen, L.R. \& Sparkes, E.C. 2001. The effect of dingo control on sheep and beef cattle in Queensland. Journal of Applied Ecology 38:76-87.

ANDELT, W. F. 1992. Effectiveness of livestock guarding dogs for reducing predation on domestic sheep. Wildlife Society Bulletin 20:55-62.

Andelt, W. F. And S. N. Hopper. 2000. Livestock guard dogs reduce predation on domestic sheep in Colorado. Journal of Range Management 53(3):259-267.

Bowns, J. E. 1976. Field criteria for predator damage assessment. Utah Science 37(1):26-30.

Campbell, K. \& Hofer, H. 1995. People and wildlife: spatial dynamics and zones of interaction. pp. 534-570. In: Sinclair, A. R. E. and P. Arcese. [Eds.]. Serengeti II: Dynamics, Management, and Conservation of an Ecosystem. University of Chicago Press. Chicago, USA.

Caughley, G. \& Sinclair, A. R. E. 1994. Wildlife Ecology and Management. Blackwell. Boston, MA, USA.

Cavalcanti, S. M. C. 2003. Manejo e controle de danos causados por espécies da fauna. pp.203-242. In: CuLLEN, L., JR., Rudran, R. \& Valladares-Padua, C. [Eds.]. Métodos de Estudo em Biologia da Conservação e Manejo da Vida Silvestre. Editora da UFPR. Curitiba, PR, Brasil.

Churcher, P. B. \& Lawton, J. H.. 1987. Predation by domestic cats in an English village. Journal of Zoology, Lond. 212:439-455.

Ciucci, P. \& Boitani, L. 1998. Wolf and dog depredation on livestock in central Italy. Wildlife Society Bulletin 26(3):504-514.

Conner, M. M., Jaeger, M. M., Weller, T. J., \& McCullough, D. R. 1998. Effect of coyote removal on sheep depredation in northern California. Journal of Wildlife Management 62(2):690-699.

Cozza, K., Fico, R., \& Battistini, M.-L. 1996. The damageconservation interface illustrated by predation on domestic livestock in central Italy. Biological Conservation 78:329-336.

Dolbeer, R. A., Holler, N. R., \& Hawthorne, D. W. 1996. Identification and control of wildlife damage. pp. 474506. In: Bookнout, T. A. [Ed.]. Research and Management Techniques for Wildlife and Habitats. $5^{\text {th }}$ ed. The Wildlife Society. Bethesda, Maryland, U.S.A.

Greentree, C., Saunders, G., McLeod, L. \& Hone, J. 2000. Lamb predation and fox control in south-eastern Australia. Journal of Applied Ecology 37:935-943. 
Harris, S. AND SAunders, G. 1993. The control of canids. Symp. Zool. Soc. Lond. 65:441-464.

Hawthorne, D. W. 1980. Wildlife damage and control. pp.411439. In: Schemnitz, S. D. [Ed.]. Wildlife Management Techniques Manual. $4^{\text {th }}$ ed. The Wildlife Society. Bethesda, Maryland, USA.

Hoogestein, R., Hoogesteijn, A., \& Mondolfi, E. 1993. Jaguar predation and conservation: cattle mortality caused by felines on three ranches in Venezuela. Symp. Zool. Soc. Lond. 65:391-407.

Hueting, R. 1991. Correcting national income for environmental losses: A practical solution for a theoretical dilemma. pp.194-213. In: CostanZA, R. [Ed.]. Ecological Economics: The Science and Management of Sustainability. Columbia University Press. New York.

Huygens, O. C. \& Hayashi, H. 1999. Using electric fences to reduce Asiatic black bear depredation in Nagano prefecture, central Japan. Wildlife Society Bulletin 27(4):959964.

KrasilchiK, M. 2003. Prática de Ensino de Biologia. Edusp. São Paulo, SP, Brasil.

Landa A., Gudvangen. K., Swenson, J. E., \& Roskaft, E.. 1999. Factors associated with wolverine Gulo gulo predation on domestic sheep. Journal of Applied Ecology 36:963-973.

Magnusson, W.E. 1993. Manejo da vida silvestre na Amazônia. pp.313-318. In: Ferreira, E. J. G., Santos, G. M., Leão, E. L. M. \& Oliveira, L. A. [Eds.]. Bases Científicas para Estratégias de Preservação e Desenvolvimento da Amazônia. Vol. 2. Instituto Nacional de Pesquisas da Amazônia. Manaus, AM, Brasil

MourÃo, G. M. 1999. Uso comercial da fauna silvestre no Pantanal: lições do passado. Pp.39-45. In: Anais do II Simpósio sobre Recursos Naturais e Sócio-econômicos do Pantanal: manejo, e Conservação. Embrapa. Corumbá, MS, Brasil.

Musiani, M., Mamo, C., Boitani, L., Callahan, C., Gates, C. C., Mattei, L., Visalberghi, E., Breck, S. \& Volpi, G. 2003. Wolf depredation trends and the use of fladry barriers to protect livestock in Western North America. Conservation Biology 17(6):1538-1547.

Nesbitt, W. H. 1983. Ecology of a feral dog pack on a wildlife refuge. pp.391-396. In: Fox, M. W. [Ed.]. The Wild Canids: Their Systematics, Behavioral Ecology and Evolution. Krieger. Malabar, Florida, USA.

Naughton-Treves, L, Grossberg, R. \& Treves, A. 2003. Paying for tolerance: rural citizen's attitudes toward wolf depredation and compensation. Conservation Biology 17(6):1500-1511.
O’Connel-Rodwell, C. E., Rodwell, T., Rice, M., \& Hart, L. 2000. Living with the modern conservation paradigm: can agricultural communities co-exist with elephants? A five-year case study in East Caprivi, Namibia. Biological Conservation 93:381-391.

Ogada, M. O., Woodroffe, R., Oguge, N. O. \& Frank, L. G. 2003. Limiting depredation by African carnivores: the role of livestock husbandry. Conservation Biology 17(6):1521-1530.

Ruth, T. K., Logan, K. A., Sweanor, L. L., Hornocker, M. G., \& Temple, L. J. 1998. Evaluating cougar translocation in New Mexico. Journal of Wildlife Management 62(4):1264-1275.

Shivik, J. A., Treves, A. \& Gallahan, P. 2003. Non-lethal techniques for managing predation: Primary and secondary repellents. Conservation Biology 17(6):1531-1537.

Treves, A. \& Karanth, K. U. 2003. Human-carnivore conflict and perspectives on carnivore management worldwide. Conservation Biology 17(6):1491-1499.

Verdade, L. M. 2001. Manejo de Fauna Silvestre: Sistemas de Aproveitamento Econômico. Texto sistematizado apresentado à Escola Superior de Agricultura "Luiz de Queiroz", Universidade de São Paulo, para o Concurso de Livre-Docência do Departamento de Produção Animal, na Especialidade Ecologia Animal, disciplina Ecologia Animal Aplicada. Piracicaba, SP, Brasil. 105pp.

VIEIRA, G. V. N. 1967. Criação de Ovinos. Melhoramentos. São Paulo, Brasil.

Wagner, K. K., Schmidt, R. H., \& Conover, M. R. 1997. Compensation programs for wildlife damage in North America. Wildlife Society Bulletin 25(2):312-319.

Title: How much is a puma worth? Economic compensation as an alternative for the conflict between wildlife conservation and livestock production in Brazil

Authors: Luciano M. Verdade \& Cláudia B. Campos

Biota Neotropica, Vol. 3 ( number 1): 2003

http://www.biotaneotropica.org.br/v4n $2 / \mathrm{pt} /$ abstract?short-communication+BN02204022004

Date received: $01 / 28 / 2004$

Revised: 06/24/2004

Accepted: 07/01/2004

ISSN 1676-0611 